\author{
Marzena WALASZEK \\ Dr, Instytut Geografii Społeczno-Ekonomicznej i Gospodarki Przestrzennej, Wydział Nauk Geograficznych i Geologicznych \\ Uniwersytet im. Adama Mickiewicza w Poznaniu \\ marwal@amu.edu.pl
}

\title{
PRZEKSZTAŁCENIA SIECI SZKOLNEJ POD WPŁYWEM ZMIAN DEMOGRAFICZNYCH W AGLOMERACJI POZNAŃSKIEJ
}

\begin{abstract}
Abstrakt: Zmiany przestrzenne i organizacyjne sieci szkolnej w aglomeracji poznańskiej w ostatnich kilkunastu latach wynikały przede wszystkim ze zmieniających się uwarunkowań demograficznych, będących przejawem procesu suburbanizacji. W wyniku tego procesu w strefie podmiejskiej dynamicznie wzrosła liczba uczniów w szkołach, tymczasem w strefie centralnej aglomeracji znacznie zmalała. Celem artykułu była charakterystyka przemian demograficznych zachodzących w ostatnich latach w aglomeracji poznańskiej oraz ich wpływu na kształtowanie sieci szkolnej.
\end{abstract}

Słowa kluczowe: edukacja, sieć szkolna, szkoły samorządowe i niesamorządowe, aglomeracja poznańska.

\section{DEVELOPMENT OF SCHOOL NETWORK UNDER THE INFLUENCE OF DEMOGRAPHIC CHANGES IN THE POZNAŃ AGGLOMERATION}

\begin{abstract}
Changes in spatial and organizational school network in the Poznań agglomeration in recent years resulted primarily from the changing demographic conditions, which are a manifestation of the suburbanization process. As a result of this process in a suburban area rapidly increased the number of pupils in schools, while in the central zone of the agglomeration, this number has decreased markedly. The aim of the article was to present the demographic changes taking place in recent years in the Poznań agglomeration and their impact on the school network.

Keywords: education, school network, governmental and non-governmental schools, Poznań agglomeration.
\end{abstract}

\section{WPROWADZENIE}

Jednym z największych aktualnie wyzwań dla oświaty w Polsce jest dostosowanie sieci szkolnej do dynamicznie zmieniających się uwarunkowań demograficznych. W przypadku przeobrażeń demograficznych zachodzących w aglomeracjach miejskich, zarówno depopulacja ich stref centralnych, jak i wzrost zaludnienia w strefach podmiejskich, prowadzą do zmian popytu i podaży na rynku usług edukacyjnych. Zmiany liczby użytkowników szkół obligują samorządy terytorialne do optymalnego dostosowania sieci szkolnej do aktualnego zapotrzebowania mieszkańców.

Przemiany demograficzne są, bez wątpienia, głównym czynnikiem rozwoju sieci szkolnej. Według A. Dziemianowicz-Bąk i J. Dzierzgowskiego (2014), sieć szkolna jest układem szkół na obszarze danej jednostki terytorialnej, a zarządzanie siecią szkolną przez samorząd gminny obejmuje m.in. czynności związane z planowaniem struktury sieci punktów szkolnych, liczbą uczniów i strukturą zatrudnienia w placówkach oraz zakładaniem bądź likwidacją placówek (tzw. kon- solidacja sieci). Należy podkreślić, że decyzje organów gminy dotyczące ustalania sieci szkolnej mają bezpośredni wpływ na dostępność placówek szkolnych dla mieszkańców. Decyzje o reorganizacji sieci szkolnej nie zapadają jednak adekwatnie w czasie do zaobserwowanych zmian demograficznych zachodzących na obszarze jednostek samorządu terytorialnego, lecz zawsze z pewnym opóźnieniem wynikającym przede wszystkim z konieczności przeanalizowania racjonalności istniejącej sieci szkolnej. Analiza aktualnych uwarunkowań oraz perspektyw rozwoju, w tym prognozowanej liczby ludności według wieku, skłania do podjęcia stosownych rozwiązań, a w rezultacie przygotowania planów reorganizacji sieci szkolnej.

Sieć szkolna nie jest układem izolowanym, działa bowiem zawsze $\mathrm{w}$ pewnym otoczeniu instytucjonalnym, a także społecznym i gospodarczym. W niniejszej pracy przeobrażenia lokalnego systemu oświaty w aglomeracji poznańskiej objaśniono na tle suburbanizacji, intensywnie zachodzącej na tym obszarze co najmniej 
od 15 lat. Według P. Lorensa (2005), a także A. Lisowskiego i M. Grochowskiego (2008), suburbanizacja $\mathrm{w}$ Polsce przejawia się $\mathrm{w}$ trzech zasadniczych aspektach przestrzennych. Są to:

1) spadek zainwestowania i depopulacja wewnątrz granic administracyjnych miasta centralnego, głównie w śródmieściu i starszych dzielnicach;

2) silny wzrost liczby mieszkańców i inwestycji poza granicami miasta centralnego, szczególnie w obrębie tzw. strefy podmiejskiej bliższej, cechującej się względną ciągłością przestrzenną zainwestowania;

3) silne związki z miastem centralnym strefy podmiejskiej dalszej (dojazdy do pracy, szkół i innych usług), z przewaga ekstensywnych form użytkowania ziemi, krajobrazowo przypominającej jeszcze tereny wiejskie.

Wszystkie te trzy strefy wykrystalizowały się także na obszarze aglomeracji poznańskiej, tworząc zwarty zespół jednostek osadniczych (duże miasto wraz ze strefą podmiejską), powstały w wyniku procesów koncentracji zabudowy i funkcji w mieście oraz jego strefie przygranicznej (Kaczmarek 2008). Strefy aglomeracji poznańskiej mają swoiste cechy społeczno-demogra- ficzne, gospodarcze i przestrzenne, które różnicują je między sobą, również w kontekście funkcjonowania oświaty. Wyznaczenie wymienionych stref na obszarze aglomeracji poznańskiej jest uzasadniane, gdyż różnią je procesy demograficzne zachodzące $\mathrm{w}$ tych strefach, a uwarunkowania rozwoju lokalnych rynków edukacyjnych stawiają przed samorządami zgoła inne wyzwania.

\section{CEL I ZAKRES BADAŃ}

Głównym celem autorki artykułu było przedstawienie przemian demograficznych, które zachodziły na obszarze aglomeracji poznańskiej w ostatnich latach oraz ich wpływu na kształtowanie sieci szkolnej w poszczególnych strefach aglomeracji. Realizacja tego celu wymagała odpowiedzi na następujące pytania badawcze:

- jak zmieniała się liczba uczniów w poszczególnych strefach aglomeracji poznańskiej?,

- jak pod wpływem zmian demograficznych zmieniała się liczba szkół w aglomeracji poznańskiej; gdzie powstały nowe szkoły, a gdzie je zlikwidowano?

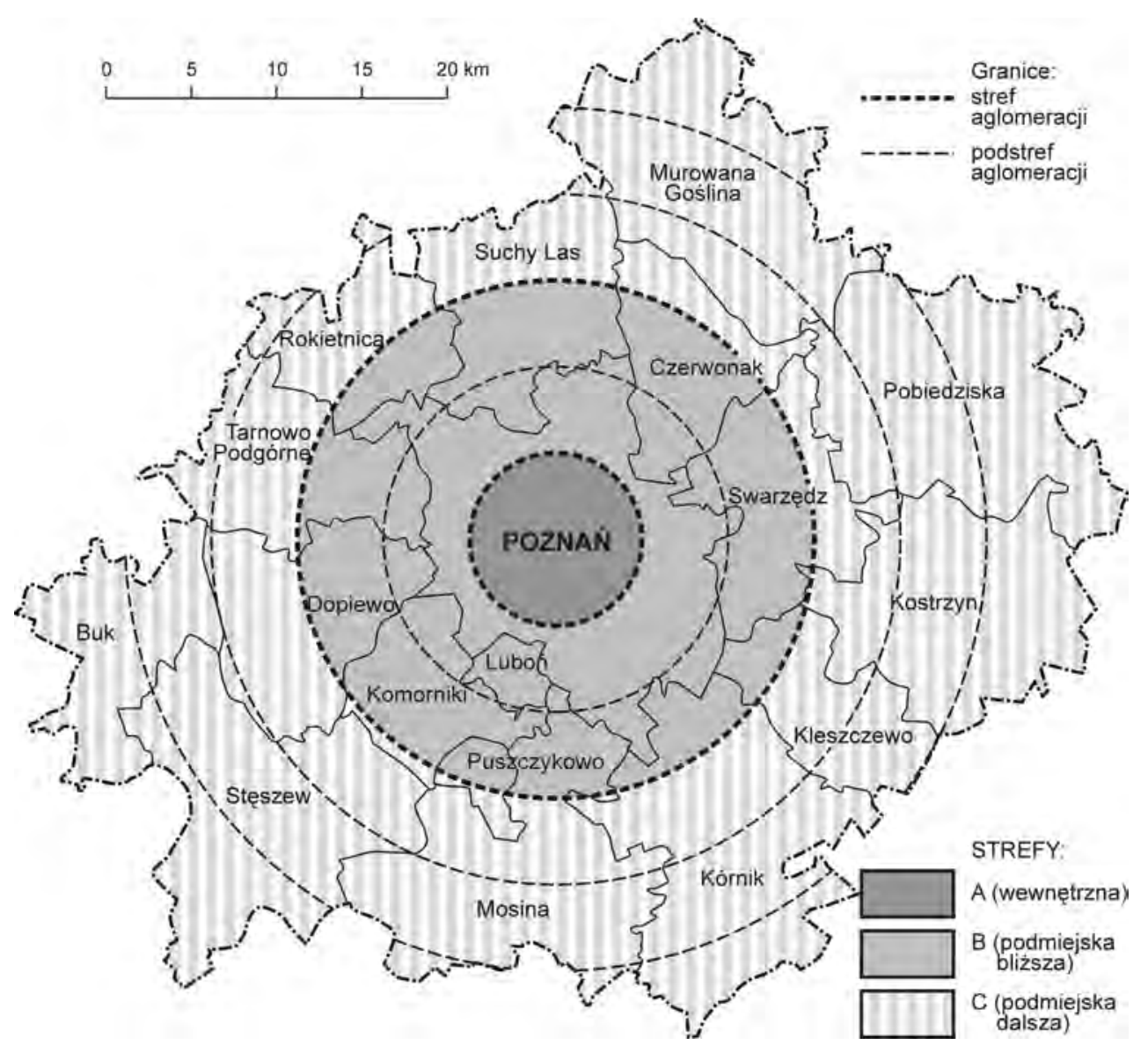

Rys. 1. Aglomeracja poznańska w układzie strefowym

Źródło: opracowanie własne 
Zakres czasowy badań demograficznych obejmuje lata 2005-2014, zmiany liczby uczniów szkół podstawowych i gimnazjalnych w strefach aglomeracji dotyczą lat 2010-2014, natomiast zmiany liczby szkół na tym obszarze to okres 2006-2014 r. Zakres czasowy analiz podyktowany został możliwością pozyskania danych udostępnionych przez Kuratorium Oświaty w Poznaniu (dane za rok szkolny 2006/2007 pochodzą z Systemu Informacji Oświatowej, który powstał właśnie w 2006 r.).

Ważnym elementem postępowania badawczego było określenie podstawowych jednostek analizy przestrzennej. Należy uznać, że dane oświatowe agregowane do poziomu gmin dostępne poprzez portal Banku Danych Lokalnych GUS są niewystarczające do prowadzenia analiz sektora edukacji w skali mniejszej, niż gmina. Konieczność prowadzenia tak szczegółowych analiz pojawia się w przypadku badań dotyczących aglomeracji miejskich, w których zmiany przestrzenne i społeczno-gospodarcze nie zachodzą z taką samą intensywnością na całych obszarach gmin, lecz często lokalnie, na poziomie pojedynczych sołectw, miejscowości czy dzielnic. Jak już zasygnalizowano, podstawową jednostką przestrzenną analiz przedstawionych $\mathrm{w}$ niniejszym artykule, były trzy strefy aglomeracji (rys. 1):

1) strefa A (wewnętrzna) - śródmieście miasta Poznania - obszar o średnicy $10 \mathrm{~km}$;

2) strefa B (podmiejska bliższa) - pierścień gmin położonych radialnie od $5-15 \mathrm{~km}$ od centrum miasta Poznania;

3) strefa $C$ (podmiejska dalsza) - pierścień gmin położonych radialnie powyżej $15 \mathrm{~km}$ od centrum miasta Poznania.

Przeprowadzenie charakterystyki pod względem demograficznym oraz wybranych cech szkół wymagało zagregowania danych przestrzennych, pozyskanych dla obrębów ewidencyjnych lub pojedynczych szkół, do wymienionych trzech stref aglomeracji (w przypadku zmian liczby uczniów wg poziomów kształcenia podstawowego i gimnazjalnego analizy przeprowadzono dodatkowo, z podziałem tych stref aglomeracji na podstrefy o promieniu $5 \mathrm{~km}$, w celu uchwycenia przestrzennego zróżnicowania badanego zjawiska). $\mathrm{W}$ ten sposób możliwe było określenie podobieństw i różnic w zakresie badanych cech w poszczególnych strefach aglomeracji.

\section{ZMIANY DEMOGRAFICZNE W UKŁADZIE STREFOWYM W AGLOMERACJI POZNAŃSKIEJ}

Według danych pozyskanych z urzędów miast i gmin, aglomerację poznańską w 2014 r. zamieszkiwało 870 tys. mieszkańców (zameldowania stałe). Największą gęstością zaludnienia cechowała się strefa centralna, z zaludnieniem 277,4 tys. osób, co stanowiło $32 \%$ mieszkańców całej aglomeracji poznańskiej. Najbardziej zaludniona była zaś strefa B (podmiejska bliższa), której liczba ludności zameldowanej na stałe w $2014 \mathrm{r}$. wynosiła 425 tys. mieszkańców (49\%).

W latach 2005-2014 liczba ludności w strefie A zmniejszyła się o 9,2\%, natomiast $\mathrm{w}$ strefach B i C wzrosła odpowiednio o $15,7 \%$ i o $17 \%$. Na tle aglomeracji poznańskiej najmłodszymi demograficznie obszarami były strefy B i C, gdzie udział ludności w przedziale wiekowym 0-18 lat przekraczał w tych strefach 20\% (tab. 1). Wskutek migracji nowych mieszkańców do strefy podmiejskiej bliższej w badanym okresie liczba osób w wieku 0-18 lat zwiększyła się tam o 12,1\%. Gęstość zaludnienia w poszczególnych strefach aglomeracji jest pochodną typu zabudowy mieszkaniowej dominującej $\mathrm{w}$ poszczególnych strefach. W strefach B i C dominuje zabudowa jednorodzinna, zaś w strefie A - wielorodzinna (zabudowa jednorodzinna stanowi $\operatorname{tam} 37 \%)$.

Tab. 1. Strefy aglomeracji poznańskiej według wybranych cech demograficznych i zagospodarowania przestrzennego (stan w 2014)

\begin{tabular}{|l|c|c|c|}
\hline \multirow{2}{*}{ Cecha } & \multicolumn{3}{c|}{ Strefy aglomeracji } \\
\cline { 2 - 4 } & $\mathrm{A}$ & $\mathrm{B}$ & $\mathrm{C}$ \\
\hline Liczba ludności & 277447 & 425257 & 169344 \\
\hline $\begin{array}{l}\text { Zmiany liczby ludności w \% } \\
\text { (2005-2014) }\end{array}$ & $-9,2$ & $+15,7$ & +17 \\
\hline Gęstość zaludnienia w osobach/km² & 4908 & 1321 & 175 \\
\hline Liczba ludności w wieku 0-18 lat & 43904 & 86856 & 37608 \\
\hline Odsetek ludności w wieku 0-18 lat & 15,8 & 20,4 & 22 \\
\hline $\begin{array}{l}\text { Zmiany liczby ludności w wieku } \\
\text { 0-18 lat (\%), 2005-2014 }\end{array}$ & $+0,6$ & $+12,1$ & $+7,6$ \\
\hline $\begin{array}{l}\text { Udział powierzchni zabudowy } \\
\text { mieszkaniowej ogółem w \% }\end{array}$ & 27 & 15,9 & 4,8 \\
\hline $\begin{array}{l}\text { Udział zabudowy mieszkaniowej } \\
\text { jednorodzinnej w \% }\end{array}$ & 37 & 84,95 & 92,5 \\
\hline
\end{tabular}

Źródło: opracowanie własne na podstawie danych urzędów miast i gmin aglomeracji poznańskiej i BDOT. 
Podsumowując, zmiany liczby mieszkańców w poszczególnych strefach wynikały głównie z intensywnego rozwoju budownictwa mieszkaniowego oraz związanych z tym procesów migracyjnych. Przemiany demograficzne oraz przestrzenne doprowadziły do zmiany liczby dzieci i młodzieży kształcącej się w szkołach aglomeracji, przy czym największy jej przyrost nastąpił w strefie podmiejskiej bliższej (B) i dalszej (C). Wzrost tej liczby spowodował „odmłodzenie” stre-fy podmiejskiej, tymczasem $\mathrm{w}$ strefie centralnej aglomeracji zaznaczył się wyraźny spadek udziału ludzi młodych (0-18 lat) w ogólnej liczbie mieszkańców.

\section{ZMIANY LICZBY UCZNIÓW W SZKOŁACH PODSTAWOWYCH I GIMNAZJALNYCH W AGLOMERACJI POZNAŃSKIEJ}

Skutkiem przemian demograficznych są zmiany liczby uczniów w szkołach podstawowych i gimnazjalnych. Charakterystyki zmian tej liczby dokonano w latach 2010-2014, w podziale na szkoły samorządowe i niesamorządowe.

Tab. 2. Zmiany liczby uczniów w szkołach podstawowych i gimnazjalnych aglomeracji poznańskiej w latach 2010-2014

\begin{tabular}{|c|c|c|c|}
\hline Szkoły & Strefa A & Strefa B & Strefa C \\
\hline \multicolumn{4}{|c|}{$\begin{array}{l}\text { Zmiany liczby uczniów w szkołach } \\
\text { (samorządowe/niesamorządowe) }\end{array}$} \\
\hline Podstawowe & $-291 / 529$ & $1765 / 32$ & $635 /-11$ \\
\hline Gimnazjalne & $-872 / 142$ & $-300 / 38$ & $-265 /-$ \\
\hline \multicolumn{4}{|c|}{$\begin{array}{c}\text { Dynamika zmian liczby uczniów w \% } \\
\text { (samorządowe/niesamorządowe) }\end{array}$} \\
\hline Podstawowe & $-1,8 / 29,6$ & $10,5 / 2,4$ & $6,3 /-8,0$ \\
\hline Gimnazjalne & $-11,9 / 11,1$ & $-4,4 / 7,7$ & $-5,3 /-$ \\
\hline
\end{tabular}

(-) - brak szkół danego typu w badanej strefie.

Źródło: opracowanie własne na podstawie danych z Kuratorium Oświaty w Poznaniu.

W strefie wewnętrznej aglomeracji poznańskiej (A) w latach 2010-2014 w szkołach samorządowych odnotowano spadek liczby uczniów na każdym badanym poziomie kształcenia (tab. 2). Największe zmiany liczby uczniów nastąpiły jednak na poziomie szkolnictwa gimnazjalnego. $\mathrm{W}$ strefie $\mathrm{A}$, pomimo spadku liczby uczniów w szkołach samorządowych, przybyło uczniów w szkołach niesamorządowych, co dotyczyło zarówno szkolnictwa podstawowego, jak i gimnazjalnego. W strefie podmiejskiej bliższej (B) miał miejsce

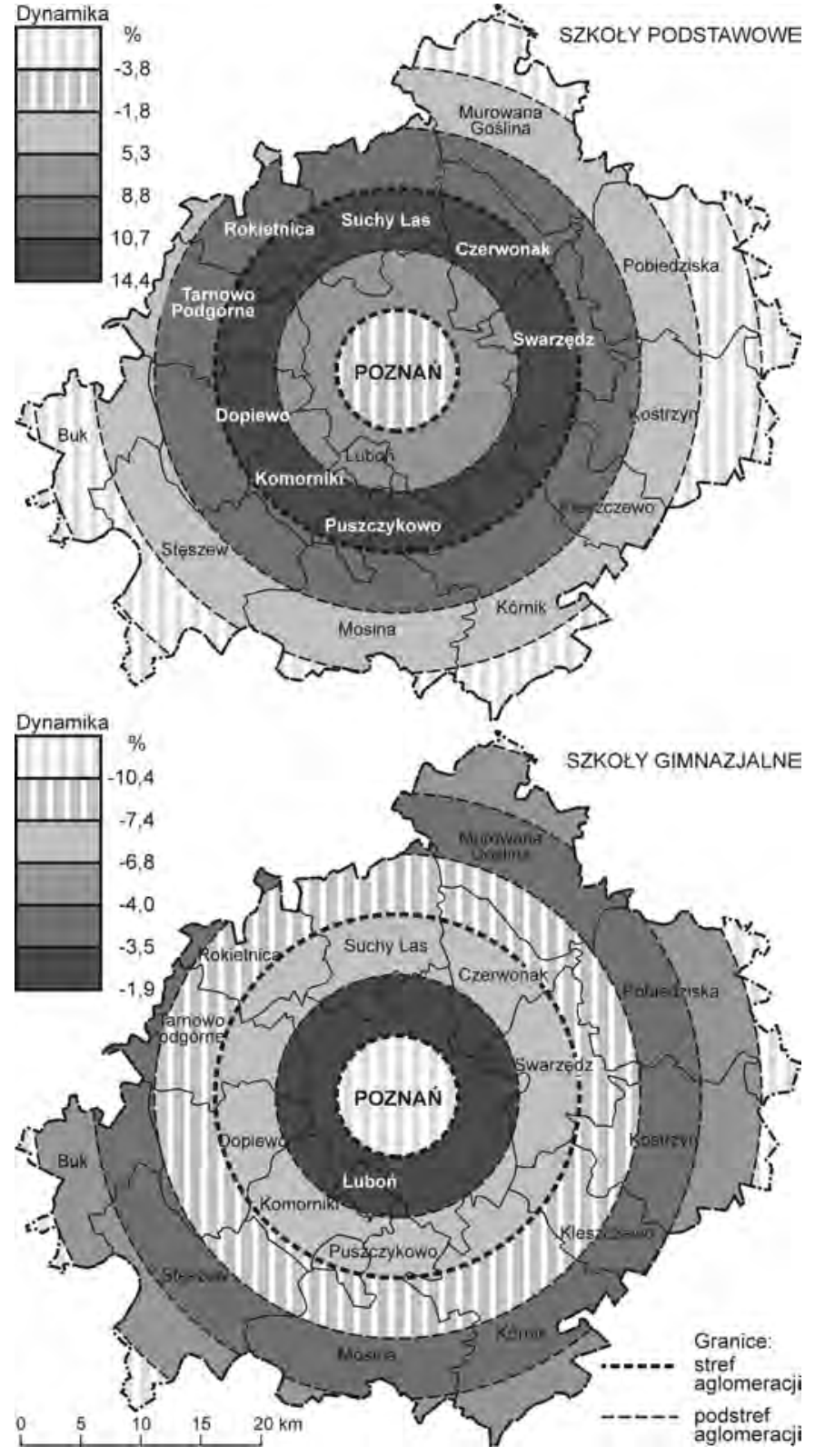

Rys. 2. Zmiany liczby uczniów w samorządowych szkołach podstawowych (A) i gimnazjalnych (B) w strefach koncentrycznych (co 5 km) aglomeracji poznańskiej (2010-2014) Źródło: opracowanie własne na podstawie danych Kuratorium Oświaty w Poznaniu

wzrost liczby uczniów szkół podstawowych samorządowych i jej spadek w szkołach gimnazjalnych samorządowych (o 4,4\%). W przypadku szkół podstawowych i gimnazjalnych niesamorządowych odnotowano wzrost liczby uczniów. Podobnie jak w strefie B, w strefie podmiejskiej dalszej (C) wzrosła liczba uczniów w szkołach podstawowych samorządowych i nastąpił spadek tej liczby w gimnazjach samorządowych. $\mathrm{Na}$ podstawie analizy zmian liczby uczniów szkół podstawowych samorządowych $\mathrm{w}$ podstrefach koncentrycznych (co $5 \mathrm{~km}$ ) wykazano, że spadek tej liczby 
nastąpił w strefie centralnej A i zewnętrznej części strefy C. W pozostałych podstrefach liczba uczniów w szkołach podstawowych samorządowych zwiększyła się, najsilniej jednak w podstrefie zewnętrznej strefy B. Oznacza to, że dynamika wzrostu liczby uczniów w samorządowych szkołach podstawowych w gminach podmiejskich w tej podstrefie była większa, niż w peryferyjnej części miasta Poznania. We wszystkich trzech strefach odnotowano spadek liczby uczniów w gimnazjach samorządowych, największy był w strefie A (rys. 2).

W przypadku szkolnictwa podstawowego samorządowego we wszystkich strefach, prócz strefy A i zewnętrznej podstrefy strefy $C$, zaznaczył się więc wzrost liczby uczniów w szkołach. Spadek tej liczby w szkołach gimnazjalnych samorządowych wystąpił we wszystkich badanych strefach, a jego dynamika w latach 2010-2014 w każdej ze stref przybrała wartości ujemne. Inne w badanym okresie były zatem w aglomeracji poznańskiej uwarunkowania funkcjonowania szkolnictwa podstawowego, a inne - gimnazjalnego samorządowego. Należy także zwrócić uwagę na stosunkowo niską wrażliwość sektora niesamorządowego na zmiany demograficzne. Pomimo spadku liczby uczniów w strefie A, na poziomie szkolnictwa podstawowego i gimnazjalnego w szkołach samorządowych, tendencja ta nie wystąpiła w szkolnictwie niesamorządowym - na każdym z badanych poziomów kształcenia liczba uczniów w szkołach niesamorządowych wzrosła.

\section{PRZEKSZTAŁCENIA SIECI SZKOLNEJ W AGLOMERACJI POZNAŃSKIEJ W LATACH 2006-2014}

Zasadniczo zmiany w rozmieszczeniu szkół w aglomeracji poznańskiej w ostatnich latach polegały na likwidacji placówek szkolnych albo ich otwieraniu na obszarach, na których nastąpił wzrost liczby ludności. W gminach aglomeracji poznańskiej, szczególnie tych drugiego pierścienia (strefa C), likwidowano lub stopniowo wygaszano głównie szkoły na słabiej zaludnionych obszarach wiejskich.

Procedurę likwidacji szkół określają szczegółowo przepisy prawne. Zgodnie z zapisami Ustawy o systemie oświaty z 7 września 1991 r. (Dz.U. 1991, nr 95, poz. 425), szkoła publiczna może być zlikwidowana z końcem roku szkolnego przez organ prowadzący szkołę po zapewnieniu przez ten organ uczniom moż- liwości kontynuowania nauki w innej szkole. Ponadto organ prowadzący jest obowiązany, co najmniej na sześć miesięcy przed terminem likwidacji, zawiadomić o tym zamiarze: rodziców uczniów (w przypadku szkoły dla dorosłych - samych uczniów), właściwego kuratora oświaty oraz organ wykonawczy jednostki samorządu terytorialnego właściwej do prowadzenia szkół danego typu (art. 59 ustawy).

W latach 2006-2014 w aglomeracji poznańskiej powstała jedna szkoła podstawowa samorządowa i 10 niesamorządowych oraz cztery gimnazja samorządowe i 10 niesamorządowych (tab. 3). Pomimo spadku liczby uczniów uczęszczających do szkół położonych w strefie A, liczba nowych szkół w tej strefie zwiększyła się w badanym okresie. Wzrost ten dotyczył jednak sektora niesamorządowego, zarówno szkolnictwa podstawowego, jak i gimnazjalnego. W przypadku szkół podstawowych niesamorządowych, powstałych w tym okresie w Poznaniu, na uwagę zasługuje ich lokalizacja w dzielnicach peryferyjnych miasta (blisko jego granic administracyjnych), w których w ostatnich latach proces suburbanizacji był dynamiczny.

W latach 2006-2014 zlikwidowano w aglomeracji dziewięć szkół podstawowych samorządowych i jedną szkołę niesamorządową oraz dziewięć gimnazjów samorządowych i dwie niesamorządowe. Od kilku lat największe zmiany związane $\mathrm{z}$ reorganizacją sieci szkolnej zachodzą w szkolnictwie gimnazjalnym, zwłaszcza w Poznaniu. Spadek liczby uczniów szkół gimnazjalnych spowodował konieczność zamykania placówek, głównie w dzielnicach, które ulegają w ostatnich latach depopulacji (strefa A). W Poznaniu w latach 2006-2014 zlikwidowane zostały również trzy szkoły podstawowe (nr 52, 44 i 86) - tab. 3 .

Tab. 3. Liczba szkół nowo powstałych i zlikwidowanych w aglomeracji poznańskiej w latach 2006-2014

\begin{tabular}{|c|c|c|c|}
\hline \multirow{2}{*}{ Szkoły } & \multicolumn{3}{|c|}{ Strefa } \\
\hline & Strefa A & Strefa B & Strefa C \\
\hline \multicolumn{4}{|c|}{ Szkoły nowo powstałe (samorządowe/niesamorządowe) } \\
\hline Podstawowe & $-/ 6$ & $-/ 4$ & $1 /-$ \\
\hline Gimnazjalne & $1 / 6$ & $-/ 4$ & $3 /-$ \\
\hline Ogółem & $1 / 12$ & $-/ 8$ & $4 /-$ \\
\hline \multicolumn{4}{|c|}{ Szkoły zlikwidowane (samorządowe/niesamorządowe) } \\
\hline Podstawowe & $1 /-$ & $4 /-$ & $4 / 1$ \\
\hline Gimnazjalne & $7 /-$ & $2 /-$ & $-/ 2$ \\
\hline Ogółem & $8 /-$ & $6 /-$ & $4 / 3$ \\
\hline
\end{tabular}

(-) - brak szkół danego typu w badanej strefie.

Źródło: opracowanie własne na podstawie danych urzędów miast i gmin aglomeracji poznańskiej. 


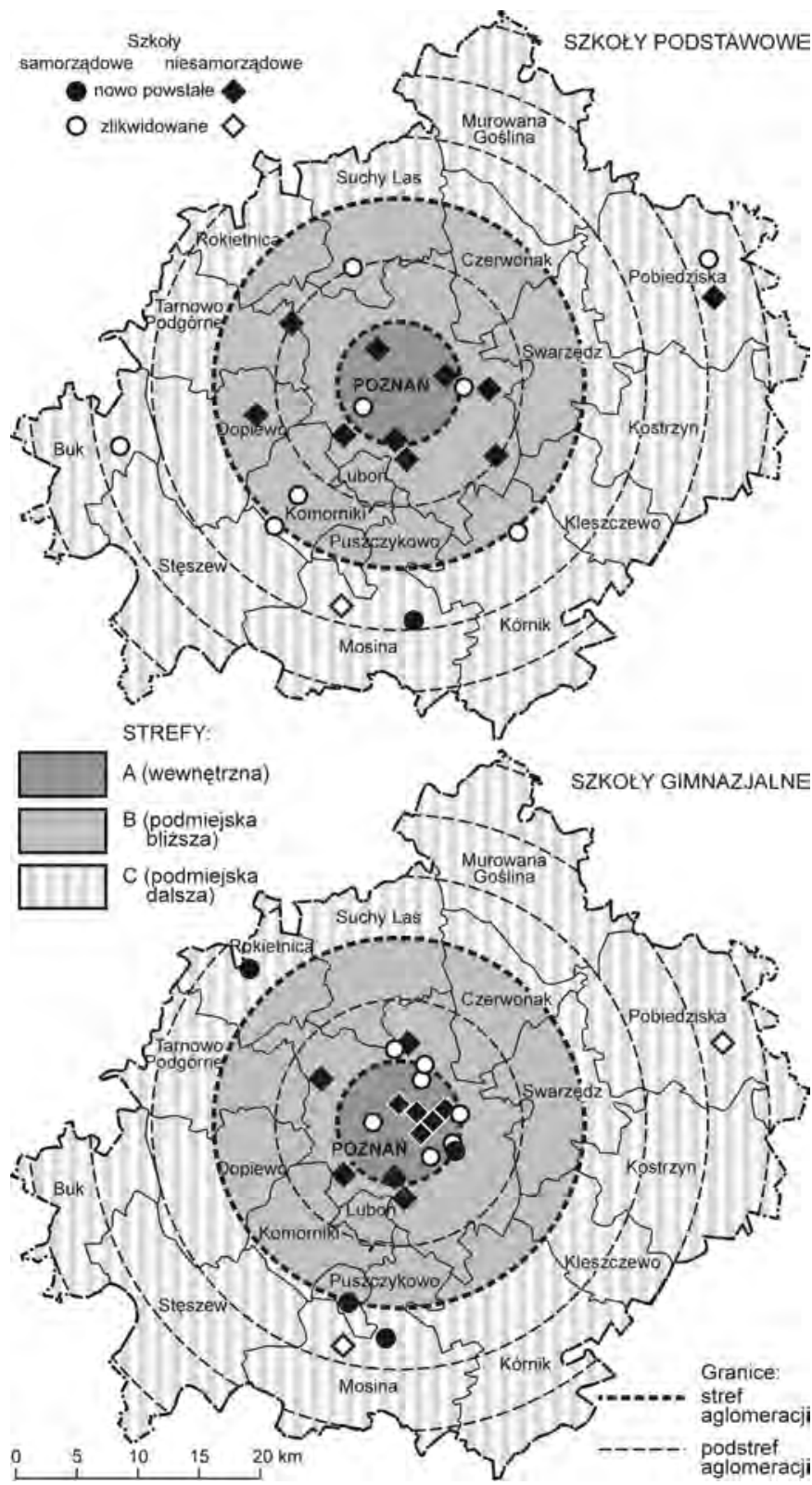

Rys. 3. Zmiany sieci szkół podstawowych i gimnazjalnych w latach 2006-2014 w aglomeracji poznańskiej Źródło: opracowanie własne na podstawie danych Kuratorium Oświaty w Poznaniu

Należy zwrócić uwagę na to, że w Poznaniu w latach 2006-2014 dynamicznie rozwijał się sektor szkolnictwa niesamorządowego. Zaledwie w ostatnich kilku latach powstały m.in. nowe szkoły podstawowe niesamorządowe: „Horyzonty” i „Skrzydła”, prowadzone przez Stowarzyszenie „Sternik” i Katolicka Szkoła Podstawowa im. Jana Pawła II. W latach 2006-2014 w Poznaniu utworzono również nowe placówki samorządowe. W 2011 r. oddano np. do użytku nową szkołę podstawową na Strzeszynie Greckim przy ulicy Hezjoda. Konieczność jej budowy wynikała z zapotrzebo- wania mieszkańców. Strzeszyn Grecki jest bowiem bardzo szybko rozwijającym się osiedlem, gdzie w ostatnich latach powstaje nowa zabudowa mieszkaniowa.

Zmiany sieci szkolnej w aglomeracji poznańskiej w latach 2006-2014 miały zatem charakter lokalny, wynikający ze zmieniających się uwarunkowań demograficznych. Szkoły podstawowe w badanym okresie likwidowano na obszarach mniej zaludnionych każdej strefy (A, B i C) - rys. 3. W przypadku gimnazjów, zamykanie szkół dotyczyło głównie strefy centralnej aglomeracji (A). Na uwagę zasługuje dynamiczny wzrost liczby szkół niesamorządowych, które w ostatnich latach powstały głównie w Poznaniu. Sieć szkół podstawowych niesamorządowych jest bardziej rozproszona niż gimnazjów niesamorządowych, odnośnie do których zauważalna jest ich koncentracja w ścisłym śródmieściu miasta Poznania. Można zatem przypuszczać, że rodzice zamieszkujący strefę silnie suburbanizującą się dowożą dzieci do szkół niesamorządowych. $\mathrm{Na}$ ten fakt wskazywałoby głównie peryferyjne usytuowanie nowych szkół podstawowych niesamorządowych względem ścisłego centrum Poznania.

\section{PODSUMOWANIE}

Decyzje dotyczące kształtowania sieci szkolnej podejmowane są zasadniczo na poziomie lokalnym (gminnym lub powiatowym), zatem procesy demograficzne powinny stanowić element badań prowadzonych na potrzeby planowania polityki oświatowej $\mathrm{w}$ jednostkach samorządu lokalnego. Badania demograficzne służące formułowaniu celów lokalnej polityki oświatowej powinny dotyczyć w szczególności: zmian liczby mieszkańców w gminie ogółem oraz w mniejszych jednostkach ewidencyjnych (miejscowości, obręby ewidencyjne, obwody szkolne), natężenia i kierunków migracji oraz prognoz demograficznych - biologicznych i pomigracyjnych (Walaszek 2016).

Problem zaspokojenia potrzeb edukacyjnych mieszkańców aglomeracji miejskich stawia przed samorządami lokalnymi (często $\mathrm{z}$ uwagi na zmienność uwarunkowań) nowe liczne wyzwania w zakresie organizacji i planowania sieci szkolnej. Dynamicznie zmieniająca się sytuacja demograficzna oraz postępujące przemiany organizacyjne i własnościowe w placówkach szkolnych powinny skłonić włodarzy miast i gmin aglomeracji poznańskiej do wypracowania wspólnej dla całej aglomeracji polityki oświatowej (lub przynajmniej koordy- 
nowania polityk lokalnych). Konieczność takiej koordynacji $\mathrm{w}$ zarządzaniu oświatą na poziomie aglomeracyjnym została wskazana w 2011 r. w „Strategii rozwoju aglomeracji poznańskiej...” (2011), w programie 4.1. Jakość i organizacja edukacji.

Należy zauważyć, że choć rozwój sektora niesamorządowego poszerza ofertę edukacyjną na rynku, to niekontrolowany wzrost liczby szkół tego typu może pogłębić problemy związane z utrzymaniem istniejących szkół samorządowych. Jako bardziej konkurencyjne (o czym świadczą choćby wyniki egzaminów zewnętrznych) szkoły niesamorządowe "przejmują" uczniów, pogłębiając tym samym ich niedobór w szkołach samorządowych, szczególnie w Poznaniu. Proces ten może zatem prowadzić do dalszego ubytku uczniów w szkołach samorządowych oraz zamykania tych szkół, co niechybnie wzbudzi protesty nauczycieli, rodziców, a także mieszkańców aglomeracji.

\section{BIBLIOGRAFIA}

Dziemianowicz-Bąk A., Dzierzgowski J., 2014, Likwidacja szkót podstawowych oraz przekazywanie stowarzyszeniom. Kontekst, proces i skutki przemian edukacyjnych w społecznościach lokalnych na podstawie analizy studiów przypadku. Raport z badania, Wyd. Instytut Badań Edukacyjnych, Warszawa.

Kaczmarek T., 2008, Aglomeracja poznańska jako region badania i działania, [w:] T. Kaczmarek, A. Mizgajski (red.), Powiat poznański. Jakość przestrzeni i jakość życia, Bogucki Wyd. Naukowe, Poznań.

Lisowski A., Grochowski M., 2008, Procesy suburbanizacji. Uwarunkowania, formy i konsekwencje, Uniwersytet Geografii Społeczno-Ekonomicznej i Gospodarki Przestrzennej Uniwersytetu Warszawskiego, Warszawa.

Lorens P., 2005, Suburbanizacja w procesie rozwoju miasta postsocjalistycznego [w:] P. Lorens (red.), Problem suburbanizacji, Biblioteka Urbanisty 7, Urbanista, Warszawa.

„Strategia rozwoju aglomeracji poznańskiej. Metropolia Poznań 2020", 2011, Centrum Badań Metropolitalnych UAM, Poznań.

Ustawa o systemie oświaty z dnia 7 września 1991 r. (Dz.U. 1991, nr 95, poz. 425).

Walaszek M., 2016, Zróżnicowanie przestrzenne dostępności szkót oraz warunków $i$ wyników nauczania $w$ aglomeracji poznańskiej, praca doktorska napisana w Instytucie Geografii Społeczno-Ekonomicznej i Gospodarki Przestrzennej UAM, pod kier. prof. Tomasza Kaczmarka, Poznań. 